\title{
Oxidation of geraniol using niobia modified with hydrogen peroxide
}

\section{Oxidación de geraniol utilizando niobia modificada con peróxido de hidrógeno}

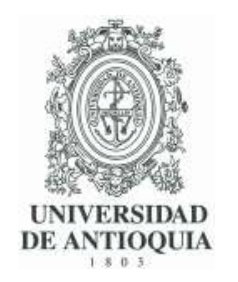

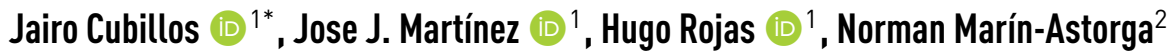

${ }^{1}$ Grupo de Catálisis, Escuela de Ciencias Químicas, Universidad Pedagógica y Tecnológica de Colombia UPTC. Avenida Central del Norte 39-115. A.A. 150003 Tunja. Boyacá, Colombia.

${ }^{2}$ Eurecat U.S. Incorporated. 13100 Bay Park Rd. C.P. 77507. Pasadena, Texas, USA.

\author{
ARTICLE INF0: \\ Received: April 27, 2018 \\ Accepted: April 16, 2019
}

\section{AVAILABLE ONLINE:}

April 22, 2019

\section{KEYWORDS:}

Niobium oxide, peroxo sites, regioselective

Óxido de niobio, sitios peroxo, regioselectividad
ABSTRACT: $\mathrm{Nb}_{2} \mathrm{O}_{5}$ bulk and $\mathrm{Nb}_{2} \mathrm{O}_{5}$ modified with $\mathrm{H}_{2} \mathrm{O}_{2}$ were studied in the epoxidation of geraniol at 1 bar and room temperature. The structural and morphological properties for both catalysts were very similar, indicating that the peroxo-complex species were not formed. The order of the reaction was one with respect to geraniol and close to zero respect to $\mathrm{H}_{2} \mathrm{O}_{2}$, these values fit well with the kinetic data obtained. The geraniol epoxidation is favored by the presence of peroxo groups, which is reached using an excess of $\mathrm{H}_{2} \mathrm{O}_{2}$. Moreover, the availability of the geraniol to adopt the three-membered-ring transition state was found as the best form for this type of compound.

RESUMEN: El óxido de niobio (niobia), $\mathrm{Nb}_{2} \mathrm{O}_{5}$ y $\mathrm{Nb}_{2} \mathrm{O}_{5}$ modificado con $\mathrm{H}_{2} \mathrm{O}_{2}$ fue explorado como catalizador en la epoxidación de geraniol a 1 bar y temperatura ambiente. Las propiedades estructurales y morfológicas de ambos catalizadores fueron muy similares, lo cual sugiere que no se formaron especies de complejo peroxo. El orden de la reacción fue uno con respecto a geraniol y cercano a cero con respecto al $\mathrm{H}_{2} \mathrm{O}_{2}$. Estos valores son consistentes con los datos cinéticos obtenidos. La epoxidación de geraniol fue favorecida en presencia de grupos peroxo, que se alcanzan utilizando un exceso de $\mathrm{H}_{2} \mathrm{O}_{2}$. Además, se encontró que, bajo las condiciones de reacción utilizadas en este trabajo, el geraniol fácilmente adoptó un estado de transición de un anillo de tres miembros como la estructura más favorable para este tipo de compuesto.

\section{Introduction}

Oxidation is one of the most important synthetic routes for the conversion of chemical compounds into valuable intermediates and products for the chemical industry. During the last decade, the peroxo and hydroperoxo complexes with different transition metals, including $\mathrm{W}, \mathrm{V}$, $\mathrm{Mo}, \mathrm{Ti}$ and $\mathrm{Nb}$, has drawn attention due to their exceptional catalytic activity in the oxidation of alkenes, aliphatic and aromatic hydrocarbon compounds [1, 2]. However, most of these works take place via homogeneous catalysis [3-5], which makes the catalytic process more expensive and difficult to execute and separate the products and catalyst, especially at large scale $[6,7]$.

The use of an environmentally friendly oxidant such as aqueous hydrogen peroxide $\left(\mathrm{H}_{2} \mathrm{O}_{2}\right)$, as a modifier on heterogeneous catalysts to make easily recyclable

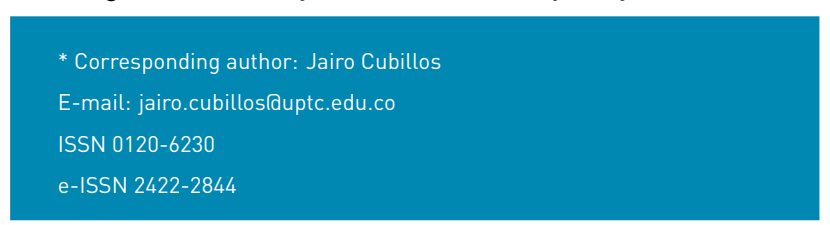

catalyst will be a challenging goal for the fine chemical industry. The catalytic technology target in this work using hydrogen peroxide as a surface modifier is developing large active sites, which can be applied for the oxidation of larger molecules. For niobia $\left(\mathrm{Nb}_{2} \mathrm{O}_{5}\right)$ bulk, it is possible to improve the oxidizer properties just with a simple modification of $\mathrm{Nb}_{2} \mathrm{O}_{5}$ surface by treatment the solid with hydrogen peroxide $\left(\mathrm{H}_{2} \mathrm{O}_{2}\right)$ [8-11]. The modified niobia shows high activity in the oxidation of cyclohexene [12], geraniol [13], and during the oxidation/dehydration of methanol to obtain dimethoxymethane [14]. In a previous work, we report the highly selective epoxidation of geraniol using $\mathrm{Nb}_{2} \mathrm{O}_{5} / \mathrm{SiO}_{2}$ and $\mathrm{Nb}_{2} \mathrm{O}_{5} / \mathrm{MCM}-41$ as heterogeneous catalysts [15], now we intended to verify the formation of peroxo sites from of the surface modification of $\mathrm{Nb}_{2} \mathrm{O}_{5}$ with $\mathrm{H}_{2} \mathrm{O}_{2}$. This kind of surface modifications can produce a relative high concentration of peroxo groups on the surface $[4,16]$, this phenomenon occurs after a prolonged interaction between the niobia with the oxidant $\left(\mathrm{H}_{2} \mathrm{O}_{2}\right)$ via a donor-acceptor mechanism to produce $\mathrm{Nb}^{5+\delta-}$ species on the $\mathrm{Nb}_{2} \mathrm{O}_{5}$ surface [17]. The peroxo groups are the catalytically active species 
responsible of the oxygen transfer from the catalyst until the substrate. However, peroxoniobate $\left(\mathrm{Nb}\left(\mathrm{O}_{2}\right)_{4}\right)^{-}$ compounds are formed at the same time, which can be isolated using alcohol solutions. In general, the formation of these homogeneous species can help to enhance the catalytic activity.

Olefins epoxidation is a widely-used transformation in the fine chemical industry. Epoxides are valuable building blocks and versatile commercial intermediates owing to the numerous reactions they may undergo. During the epoxidation reaction, it is important to eliminate the acidity of the catalytic material to control the selectivity towards epoxide. $\mathrm{H}_{2} \mathrm{O}_{2}$ is an attractive option as an oxidant that can epoxidize different compounds in the presence of various transition metal-containing catalysts, obtaining just water as a by-product. Another favorable advantage is the use of heterogeneous catalysts for easy separation from products and regeneration in some cases. Therefore, the development of heterogeneous catalytic systems for oxidation reactions using $\mathrm{H}_{2} \mathrm{O}_{2}$ as oxidant is highly demanded. In this aspect, the development of recyclable oxidation catalyst with high catalytic performance is a key issue.

The mode of the oxidant activation on the catalyst surface determines the selectivity and the formation of peroxo sites, these play an important role during the oxidation reactions [14]. In this paper, the oxidation of geraniol was examined over $\mathrm{Nb}_{2} \mathrm{O}_{5}$ treated previously with $\mathrm{H}_{2} \mathrm{O}_{2}$ for understanding the catalytic behavior and the nature of the active sites in $\mathrm{Nb}_{2} \mathrm{O}_{5}$.

\section{Experimental section}

\subsection{Chemicals}

The following compounds were used: Niobium $\left(\mathrm{Nb}_{2} \mathrm{O}_{5}\right)$ (Sigma-Aldrich > 99.9\%), $\mathrm{NH}_{3} \cdot \mathrm{H}_{2} \mathrm{O}$ (J.T. Baker, 37\%), $\mathrm{H}_{2} \mathrm{O}_{2}$ (Fluka, 30\%), geraniol (Sigma-Aldrich > 98\%) and methanol (Sigma, > 99.8\%). All chemicals were high-grade products and used without further purification.

\subsection{Catalysts preparation}

The $\mathrm{Nb}_{2} \mathrm{O}_{5}$ was used without further treatment. A peroxoniobate Ammonium tetraperoxoniobate $\left(\left(\mathrm{NH}_{4}\right)_{3}{ }^{+}\left[\mathrm{Nb}\left(\mathrm{O}_{2}\right)_{4}\right]^{-}\right)$was synthesized using the procedure reported by [6]. The obtained solid was labelled as $\mathrm{Nb}_{2} \mathrm{O}_{5} / \mathrm{H}_{2} \mathrm{O}_{2}$. In a typical procedure, $\mathrm{Nb}_{2} \mathrm{O}_{5}(1 \mathrm{~g})$ in distilled water $(25 \mathrm{~mL})$ with a $35 \mathrm{wt} . \%$ solution of $\mathrm{H}_{2} \mathrm{O}_{2}$ $(25 \mathrm{ml})$ and ammonia $(6 \mathrm{ml}, 25 \mathrm{wt} . \%$ solution) were placed in a round bottom flask. The mixture was stirred for a few hours. When the solid was totally dissolved, acetone was added dropwise $(100 \mathrm{ml})$ under stirring, a white precipitate was formed, which was filtered, washed with acetone and air-dried.

\subsection{Catalysts characterization}

The textural properties of the catalysts were determined by nitrogen adsorption at $77 \mathrm{~K}$ using the conventional technique on Micromeritics ASAP 2020 equipment. The surface area was calculated using a multipoint Brunauer-Emmett-Teller (BET) model. The pore size distribution was obtained by BJH model, the total pore volume was estimated at a relative pressure of 0.99 .

The XRD patterns were obtained on a PANalytical $\mathrm{X}$-Pert-Pro diffractometer using $\mathrm{Ni}$ filtered and $\mathrm{Cu} k \alpha$ radiation. Raman Spectra were obtained by Jobin-Yvon equipment model T64000 with a detector CCD. Spectra for each solid were taken over the range of $100-900 \mathrm{~cm}^{-1}$, scanning at a step size of $1.0 \mathrm{~cm}^{-1}$ with an integration time constant of $1 \mathrm{~s}$.

The XPS data were obtained in a Thermo Scientific Escalab $250 \mathrm{XI}$ spectrometer. Measurements were performed at room temperature with monochromatic Al $K \alpha(\mathrm{hv}=1486.6 \mathrm{eV})$ radiation. The analyzer was operated at $25 \mathrm{eV}$ pass energy and a step size of $0.05 \mathrm{eV}$. To ensures that the ambient oxygen does not interfere with the sample analysis, the solids were first degassed in a vacuum pre-chamber of $10^{-7} \mathrm{mbar}$, and then the work vacuum is adjusted in the analytical chamber at a value of $6.3 \times 10^{-9}$ mbar. C 1s signal 1284.6 $\mathrm{eV}$ ) was used as internal energy reference in all the experiments. Determination of core-level peak positions was accomplished after background subtraction per Shirley using peak XPS software. Peaks in a spectrum were fitted by a combination of Gauss and Lorentz curves, which also allowed separating overlapping peaks.

\subsection{Catalytic activity evaluation}

Catalytic reactions were performed in a low-pressure glass reactor equipped with a magnetic bar. $\mathrm{Nb}_{2} \mathrm{O}_{5}$ or $\mathrm{Nb}_{2} \mathrm{O}_{5} / \mathrm{H}_{2} \mathrm{O}_{2}(10 \mathrm{mg})$ and $\mathrm{H}_{2} \mathrm{O}_{2}(30 \% \mathrm{wt}, 1 \mathrm{mmol})$ were placed into the reactor under $N_{2}$ at $400 \mathrm{rpm}$ for $2 \mathrm{~h}$ at room temperature. The inert atmosphere was necessary to avoid the presence of molecular oxygen as oxidant. Then geraniol, was added, the mixture was maintained for $4 \mathrm{~h}$ under nitrogen atmosphere under agitation. The reaction mixture (catalyst, geraniol and $\mathrm{H}_{2} \mathrm{O}_{2}$ ) was diluted with distinct solvents $(2 \mathrm{ml})$, and then the solution was separated from the catalyst by simple filtration. The effect of geraniol concentration was studied in the concentration range of 0.25 to $3 \mathrm{mmol}$. The temperature was varied from 293 to $333 \mathrm{~K}$ and the $\mathrm{Nb}_{2} \mathrm{O}_{5} / \mathrm{H}_{2} \mathrm{O}_{2}$ weight from 4 to 10 
mg. To prevent any mass-transfer resistance, the catalyst particle sizes around $100 \mu \mathrm{m}$ and stirring rates from 200 to $600 \mathrm{rpm}$ were used.

The reaction mixture quantification and identification were performed by a Varian 3800 gas chromatograph equipped with Saturn 200 mass detector and a capillary column $\beta$-DEX $(30 \mathrm{~m} \times 0.25 \mathrm{~mm})$. The relative peak area of substrates and products using a normalization method determined the conversion and selectivity. For this, a comparison between elution times of the reaction products with authentic samples was performed.

\section{Results and discussion}

\subsection{Catalyst characterization}

Surface area, pore size distribution and pore volume were determined from nitrogen adsorption/desorption isotherms (see Figure 1). Figure 1 shows the isotherms obtained for $\mathrm{Nb}_{2} \mathrm{O}_{5}$ and $\mathrm{Nb}_{2} \mathrm{O}_{5} / \mathrm{H}_{2} \mathrm{O}_{2}$ catalysts, which are type IV with $\mathrm{H} 1$ desorption hysteresis loop. The late and steep adsorption step shows the relatively large pore size and narrow pore size distribution (PSD); this type of hysteresis loop is associated with structured porous materials, consisting of spherical cavities with fairly regular array, and narrow PSD. Table 1 details the textural parameters determined by $N_{2}$ physisorption, including BET surface area, pore size and pore volume. Both samples show similar textural properties and no differences were observed after the treatment with $\mathrm{H}_{2} \mathrm{O}_{2}$ suggesting that the treatment with $\mathrm{H}_{2} \mathrm{O}_{2}$ does not have any effect on the morphological properties of the catalysts studied.

Table $1 N_{2}$ physisorption data obtained from catalysts synthetized

\begin{tabular}{lccc}
\hline Catalysts & $\begin{array}{c}\mathbf{S}_{\mathbf{B E T}}, \\
\mathbf{m}_{\mathbf{2}} / \mathbf{g}\end{array}$ & $\begin{array}{c}\text { Pore volume, } \\
\mathbf{m l} / \mathbf{g}\end{array}$ & $\begin{array}{c}\text { Pore size, } \\
\mathbf{n m}\end{array}$ \\
\hline $\mathrm{Nb}_{2} \mathrm{O}_{5}$ & 3.5 & 0.009 & 10.2 \\
$\mathrm{Nb}_{2} \mathrm{O}_{5} / \mathrm{H}_{2} \mathrm{O}_{2}$ & 3.9 & 0.010 & 10.7 \\
\hline
\end{tabular}

The morphological features of $\mathrm{Nb}_{2} \mathrm{O}_{5}$ and $\mathrm{Nb}_{2} \mathrm{O}_{5} / \mathrm{H}_{2} \mathrm{O}_{2}$ catalysts are presented on Figure 2. X-ray diffraction (XRD) patterns of the catalysts confirmed the crystalline and well-defined structure of $\mathrm{Nb}_{2} \mathrm{O}_{5}$. The presence of $\mathrm{Nb}_{2} \mathrm{O}_{5}$ crystallites is confirmed for both samples showing diffraction peaks at $2 \theta=22.5^{\circ}, 28.5^{\circ}, 36.7^{\circ}$, $46.1^{\circ}, 50.7^{\circ}, 55.2^{\circ}$ and $56.1^{\circ}$ assigned to the crystal planes (001), (100), (101) (002), (110), (102) and (111), respectively. It was also shown that the porosity and hexagonal structure of $\mathrm{Nb}_{2} \mathrm{O}_{5}$ and $\mathrm{Nb}_{2} \mathrm{O}_{5} / \mathrm{H}_{2} \mathrm{O}_{2} \mathrm{IT}-$ $\mathrm{Nb}_{2} \mathrm{O}_{5}$, JCPDS card \# 28-0317) catalysts remained intact after hydrogen peroxide treatment in agreement with $N_{2}$ desorption/adsorption results (see Table 1). No evidence was observed for a good match with the experimental and the theoretical powder diffraction patterns calculated by [18] for $\left(\mathrm{NH}_{4}\right)_{3}\left[\mathrm{Nb}\left(\mathrm{O}_{2}\right)_{4}\right]$ which was synthetized using the same $\mathrm{H}_{2} \mathrm{O}_{2}$ method. Although, peroxo species complexes are formed, they were not capable of modifying the structural and textural properties, which is in agreement with the $N_{2}$-physisorption results.

The surface composition of $\mathrm{Nb}_{2} \mathrm{O}_{5} / \mathrm{H}_{2} \mathrm{O}_{2}$ catalyst was determined by X-ray photoelectron spectroscopy (XPS). Figures $3 a$ and $3 b$ illustrate the deconvolution curves of 0 $1 \mathrm{~s}$ and $\mathrm{Nb} 3 \mathrm{~d}$ core levels. The $\mathrm{Nb} 3 \mathrm{~d}$ spectra (Figure $3 \mathrm{a}$ ) were deconvoluted using triplet lines attributed to $\mathrm{Nb}^{+5}$ phases $[19,20]$. The binding energy of $\mathrm{Nb} 3 d_{5 / 2}$ and $\mathrm{Nb}$ $3 d_{3 / 2}$ lines was equal to 206.6 and $209.2 \mathrm{eV}$, respectively, with accuracy of $\pm 0.1 \mathrm{eV}$. The 0 1s spectral line consisted of one doublet (Figure $3 \mathrm{~b}$ ) of different oxygen phases, attributed to oxygen atoms associated at two chemical bonds. The peak located at $529.9 \mathrm{eV}$ corresponds to $\mathrm{Nb}-\mathrm{O}$ bond and the peak close to $532 \mathrm{eV}$ attributed to the formation of additional oxygenated groups on the surface of the catalyst. It is indicated that the peroxo group formation could be observed analyzing the region between 500 - 540 $\mathrm{eV}$ in the XPS spectrum $[4,15,20]$. They found that the peak around $532 \mathrm{eV}$ was not observed for the commercial or synthetized $\mathrm{Nb}_{2} \mathrm{O}_{5}$ sample $[4,19]$. There are two views about XPS of niobium oxides data in the literature. One group of authors claims that the peaks at $206 \mathrm{eV}$ and at 205.4-205.6 eV correspond to $3 d_{5 / 2}$ peaks of $\mathrm{Nb}^{+5}$ and $\mathrm{Nb}^{+4}$, respectively $[21,22]$, while another group assigns them to $\mathrm{Nb}^{+4}$ and $\mathrm{Nb}^{+3}[23,24]$. Our interpretation agrees with that of the first group. Based on the empirical relationship $(\Delta(O-N b))$ between 01 s and $\mathrm{Nb} 3 d_{5 / 2}$, it is possible to corroborate that the oxidation state of peroxoniobate is $\mathrm{Nb}^{+5}$ [25].

Raman spectroscopy was used to determine the vibration and rotation information in relation to the chemical bonds and symmetry in the $\mathrm{Nb}_{2} \mathrm{O}_{5} / \mathrm{H}_{2} \mathrm{O}_{2}$ structure, to find the finger print region of the spectra. In Figure 4, the Raman spectra of $\mathrm{Nb}_{2} \mathrm{O}_{5} / \mathrm{H}_{2} \mathrm{O}_{2}$ catalyst is shown. The spectrum displays the intensities of the $\mathrm{Nb}-\mathrm{O}$ bending modes between $600-700 \mathrm{~cm}^{-1}$ corresponding to $\mathrm{Nb}_{2} \mathrm{O}_{5}$ structure. The broad peak detected at $694 \mathrm{~cm}^{-1}$ confirms the presence $\mathrm{Nb}_{2} \mathrm{O}_{5}$ in agreement with XRD analysis. A similar spectrum has been reported by [26]. They associated the broad band at $694 \mathrm{~cm}^{-1}$ with the formation of $\mathrm{T}-\mathrm{Nb}_{2} \mathrm{O}_{5}$ phase. The $\mathrm{T}-\mathrm{Nb}_{2} \mathrm{O}_{5}$ phase consists in $4 \times 4$ blocks that form the corner-shared octahedral of $\mathrm{NbO}_{6}$, each block is connected sharing the edges of the octahedron [27].

The high intensity observed in the band at $694 \mathrm{~cm}^{-1}$ for the 


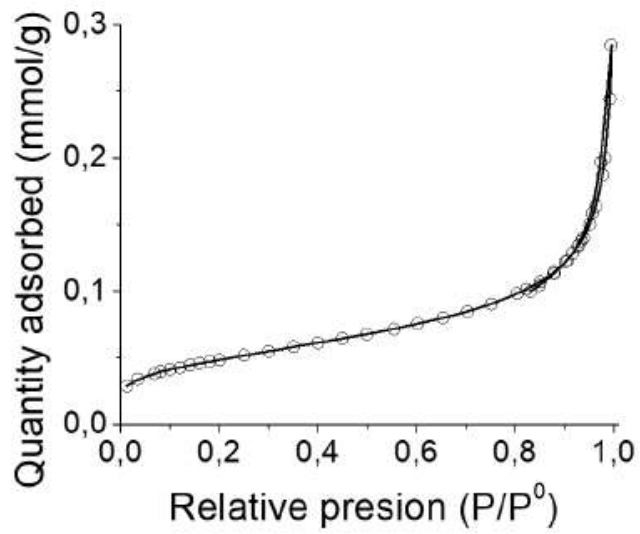

(a)

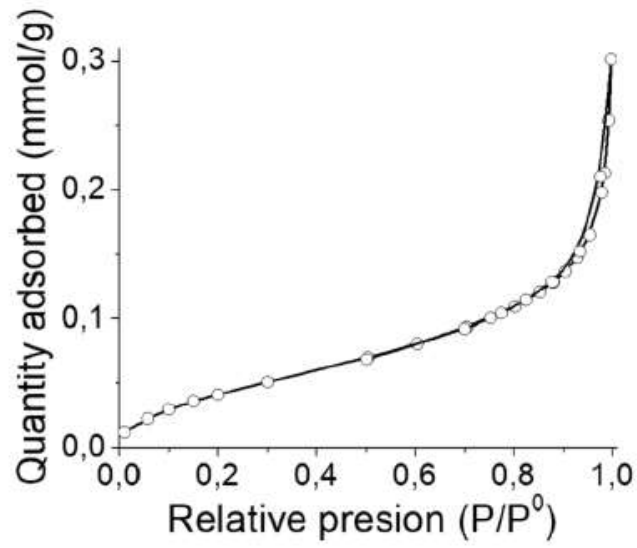

(b)

Figure 1 Nitrogen adsorption-desorption isotherms of solids: $\mathrm{Nb}_{2} \mathrm{O}_{5}$ bulk (left) and (b) $\mathrm{Nb}_{2} \mathrm{O}_{5} / \mathrm{H}_{2} \mathrm{O}_{2}$ (right)

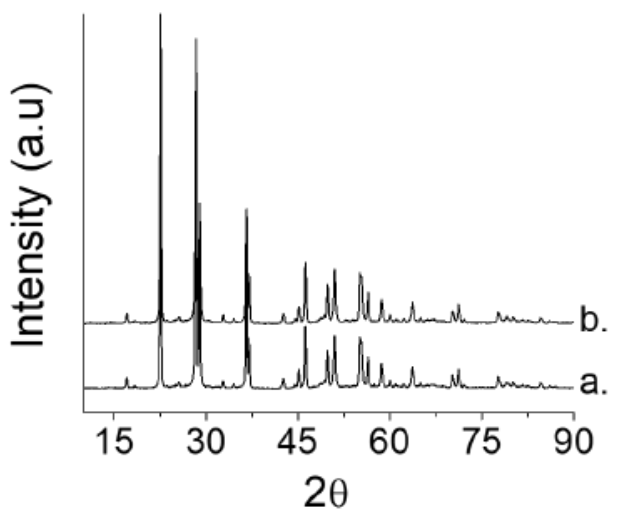

Figure $2 \mathrm{X}$-ray diffraction pattern of catalysts: (a) $\mathrm{Nb}_{2} \mathrm{O}_{5}$ bulk and (b) $\mathrm{Nb}_{2} \mathrm{O}_{5} / \mathrm{H}_{2} \mathrm{O}_{2}$ synthetized

$\mathrm{Nb}_{2} \mathrm{O}_{5} / \mathrm{H}_{2} \mathrm{O}_{2}$ catalyst, could be due to the extensive edge sharing of the octahedral. The bending vibrations at 540 , 456 and $375 \mathrm{~cm}^{-1}$ are associated to distortions that may result in significant variations in the $\mathrm{Nb}-\mathrm{O}$ lengths. Raman band between 300 and $150 \mathrm{~cm}^{-1}$ is due to the bending modes of $\mathrm{Nb}-\mathrm{O}-\mathrm{Nb}$ linkages [28] and the shoulder band at $815 \mathrm{~cm}^{-1}$ can be assigned to stretching vibrations of the peroxo groups $[15,18]$. The peak at $229 \mathrm{~cm}^{-1}$ indicates the presence of $\mathrm{Nb}-\mathrm{OH}$ bond, there were no other peaks noted, suggesting that no impurities were present.

\subsection{Catalytic activity}

Geraniol is an interesting substrate to be epoxidized to epoxy- or diepoxygeraniol. The selectivity to the desired epoxy must also be considered. In general, the epoxidation of geraniol occurs at the allylic double bond as was already observed by [29] and [13]. In this work, we used $\mathrm{Nb}_{2} \mathrm{O}_{5}$ and ammonium tetraperoxoniobate $\left(\left(\mathrm{NH}_{4}\right)_{3}{ }^{+}\left[\mathrm{Nb}\left(\mathrm{O}_{2}\right)_{4}\right]^{-}\right)$ labeled $\mathrm{Nb}_{2} \mathrm{O}_{5} / \mathrm{H}_{2} \mathrm{O}_{2}$. As can be seen from XRD, XPS and Raman spectroscopy, in the synthesis of this latter compound, the treatment of $\mathrm{Nb}_{2} \mathrm{O}_{5}$ with $\mathrm{H}_{2} \mathrm{O}_{2}$ did not modify the $\mathrm{Nb}_{2} \mathrm{O}_{5}$ structure and of peroxoniobate species $\left[\mathrm{Nb}\left(\mathrm{O}_{2}\right)_{4}\right]^{-}$was not observed. The formation of ammonium tetraperoxoniobate $\left(\left(\mathrm{NH}_{4}\right)_{3}{ }^{+}\left[\mathrm{Nb}\left(\mathrm{O}_{2}\right)_{4}\right]^{-}\right)$ was not evidenced in this work, as indicated by XRD, XPS and Raman. However, $\mathrm{Nb}_{2} \mathrm{O}_{5}$ treated with $\mathrm{H}_{2} \mathrm{O}_{2}$ promotes the formation of peroxo species on the $\mathrm{Nb}_{2} \mathrm{O}_{5}$ surface, which may be related to its catalytic behavior. The new sites on this catalyst should favor the epoxidation reaction. Table 2 summarizes the results obtained for the catalytic activity, expressed in terms of conversion and selectivity to citral, allyl epoxide and others, which were the only products obtained in all cases. To corroborate if the epoxidation is going in the absence of catalyst, blank experiments (without catalyst) were carried out.

Table 2 Selectivity and activity obtained for the oxidation of geraniol over $\mathrm{Nb}_{2} \mathrm{O}_{5}$ and $\mathrm{Nb}_{2} \mathrm{O}_{5} / \mathrm{H}_{2} \mathrm{O}_{2}$ catalysts

\begin{tabular}{lcccc}
\hline Catalysts & $\begin{array}{c}\text { Conversion, } \\
\%\end{array}$ & \multicolumn{3}{c}{ Selectivity, } \\
\cline { 3 - 5 } & & Citral & $\begin{array}{c}\text { Allyl } \\
\text { epoxide }\end{array}$ & 0thers \\
\hline $\mathrm{Nb}_{2} \mathrm{O}_{5}$ & 20 & 7 & 86 & 7 \\
$\mathrm{Nb}_{2} \mathrm{O}_{5} / \mathrm{H}_{2} \mathrm{O}_{2}$ & 17 & 14 & 80 & 6 \\
None & $<1$ & 25 & 46 & 28 \\
\hline
\end{tabular}

The main product obtained was allyl epoxide in all catalysts studied. No significant differences were observed in the catalytic activity using $\mathrm{Nb}_{2} \mathrm{O}_{5}$ treated with $\mathrm{H}_{2} \mathrm{O}_{2}$, which can be attributable to the amount of $\mathrm{H}_{2} \mathrm{O}_{2}$ used during the synthesis of $\mathrm{Nb}_{2} \mathrm{O}_{5} / \mathrm{H}_{2} \mathrm{O}_{2}$. The high selectivity at the allyl epoxide is due to the oxidation of the conjugated $\mathrm{C}=\mathrm{C}$ double bond and the carbonyl function, respectively (see 

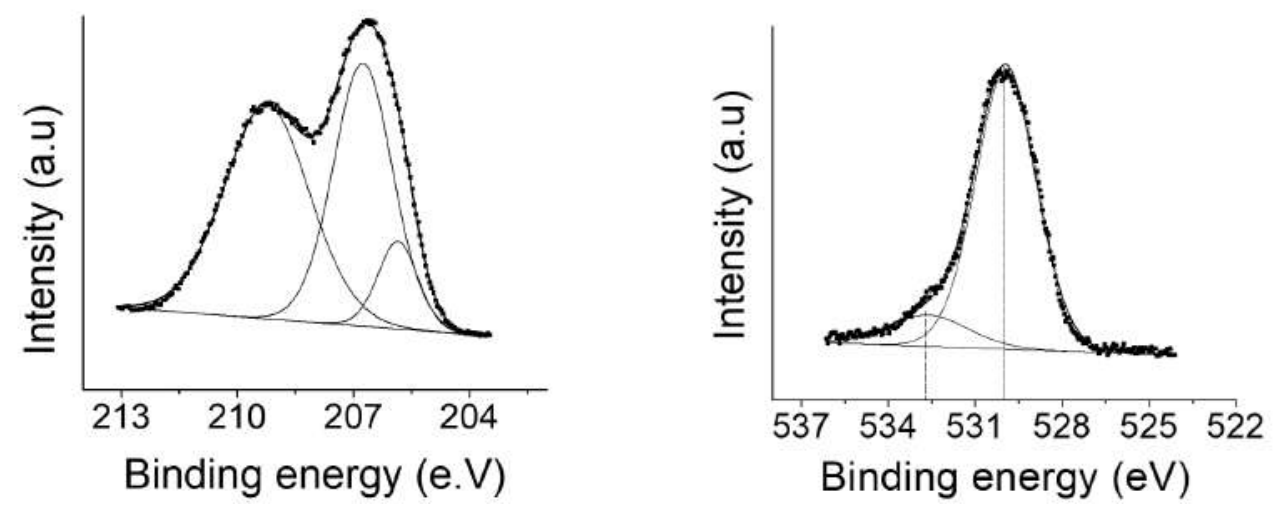

(a)

(b)

Figure 3 XPS profiles for $\mathrm{Nb} 3 \mathrm{~d}$ (left) and $\mathrm{O} 1 \mathrm{~s}$ (right) spectral lines of $\mathrm{Nb}_{2} \mathrm{O}_{5} / \mathrm{H}_{2} \mathrm{O}_{2}$ catalyst

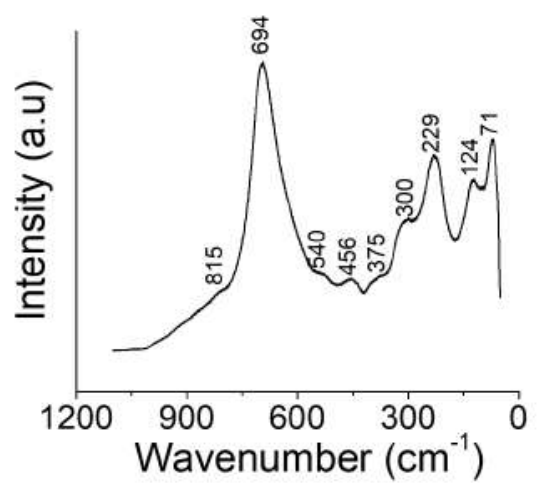

Figure 4 Raman spectra for the $\mathrm{Nb}_{2} \mathrm{O}_{5} / \mathrm{H}_{2} \mathrm{O}_{2}$ synthetized

Figure 5). The epoxide selectivity should be generated at peroxo sites and electronic structure assumptions, which is confirmed because the most nucleophilic group $\mathrm{C}=\mathrm{C}$ double bond in the geraniol molecule is predominantly epoxidized [30], thus, the differences in selectivity observed is, at least in part, due to conversion «the higher the conversion, the higher epoxide selectivity», when is compared under the same reaction conditions. The other compounds are the sum of the other epoxide and glycols formed by the reaction between epoxides and $\mathrm{H}_{2} \mathrm{O}$ in the Lewis acid sites. Recently, Nowak and colleagues reported that the catalytic properties of niobium-based catalysts are very sensitive to the type of support used. In this study, the best result was $60 \%$ selectivity to all epoxides using $\mathrm{Nb}$ (Co)SBA-15 as catalyst [31].

To evaluate the effect of solvent during the product extraction, the oxidation of geraniol over the $\mathrm{Nb}_{2} \mathrm{O}_{5} / \mathrm{H}_{2} \mathrm{O}_{2}$ catalyst was tested in different solvents (see Table 3). The conversion decreases as the dielectric constant of solvents decreases when acetonitrile, dichloromethane and dioxane were used as solvent, while using methanol,

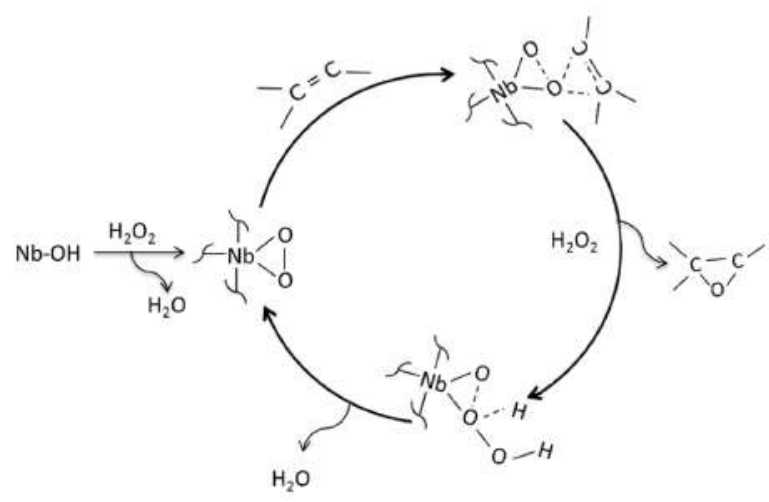

Figure 5 Proposed Geraniol oxidation pathway

the conversion increases between 2 and 3 times compared with the other solvents. This phenomenon can be explained because methanol is capable to form hydrogen bonds, which increases the epoxide extraction obtaining a more efficient catalytic system.

Table 3 Conversion using different solvents for the oxidation of geraniol over $\mathrm{Nb}_{2} \mathrm{O}_{5} / \mathrm{H}_{2} \mathrm{O}_{2}$ catalyst

\begin{tabular}{lcc}
\hline Solvent & $\begin{array}{c}\text { Dielectric } \\
\text { Constant (k) }\end{array}$ & Conversion*\% \\
\hline Methanol & 33 & 17 \\
Acetonitrile & 37 & 7 \\
Dichloromethane & 9.1 & 6 \\
Dioxane & 2.3 & 5 \\
\hline
\end{tabular}

*After $4 \mathrm{~h}$

The effect of the stirring speed in the range from 200 to $600 \mathrm{rpm}$ was studied (not shown). In a typical profile, the initial rate increase as a function of stirring speed; 
however, no significant effect on the rate was observed at stirring rates over $600 \mathrm{rpm}$, indicating the absence of mass transfer resistance.

To determine the order of reaction, the results were expressed as $\log r_{0}$ vs $\log \left(\mathrm{C}_{\text {GERANIOL }}\right)$. The initial rates were calculated using a third-order polynomial equation, during the consumption of geraniol with the reaction time. The dependence respect to geraniol (reaction order) varied from 0.8 to 1.1 , but it depends on the temperature employed. It was reported that during the oxidation of benzyl alcohol over tungstic acid describes similar results, it was found a first-order dependence with respect of benzyl alcohol concentration ( $\mathrm{BzOH})$ and completely independent respect to the $\mathrm{H}_{2} \mathrm{O}_{2}$ concentration used [32].

The formation of peroxo sites occurs after prolonged contact of time between the niobium surfaces with $\mathrm{H}_{2} \mathrm{O}_{2}$. In addition, a high efficiency during the activation of these peroxo sites using $\mathrm{H}_{2} \mathrm{O}_{2}$ was observed during the progress of reaction. This effect is expected due to the reaction zero order obtained for $\mathrm{H}_{2} \mathrm{O}_{2}$, confirming that high amounts of $\mathrm{H}_{2} \mathrm{O}_{2}$ are necessary to lead the reaction.

A proposed mechanism pathway for the oxidation of geraniol involves the activation and/or formation of peroxo sites by the reaction between $\mathrm{H}_{2} \mathrm{O}_{2}$ and $\mathrm{Nb}_{2} \mathrm{O}_{5} / \mathrm{H}_{2} \mathrm{O}_{2}$ (see Figure 5). The nucleophilic allylic olefin group on geraniol molecule attacks the electrophilic oxygen of the $\mathrm{Nb}$-peroxo group in a concerted oxygen-transfer step, forming a three-membered-ring transition state, which gives the allylic epoxide [33], as it is observed in Figure 5. In fact, a reaction order of one with respect to geraniol can consider the reaction between the peroxo sites and geraniol as the rate-controlling step.

The initial catalytic activity was recovered when the catalyst used was treated in the same way as is described in experimental part.

\section{Conclusions}

The activation of $\mathrm{Nb}_{2} \mathrm{O}_{5}$ catalyst with $\mathrm{H}_{2} \mathrm{O}_{2}$ favors the peroxo-sites formation more than peroxoniobate isolates species on the surface. The formation of peroxo sites is essential in $\mathrm{Nb}_{2} \mathrm{O}_{5}$ bulk for the geraniol epoxidation that is conducted by the formation of a three-membered-ring transition state that gives the good selectivity to the allylic epoxide. Surface modification is the key issue for controlling the product distribution in the oxidation of geraniol. No change in the textural and morphologic properties were evidenced by treating $\mathrm{Nb}_{2} \mathrm{O}_{5}$ with $\mathrm{H}_{2} \mathrm{O}_{2}$. The oxidation reaction is of first order with respect to the geraniol concentration and order zero with respect to $\mathrm{H}_{2} \mathrm{O}_{2}$ concentration.

\section{Acknowledgements}

We would like to thank VIE-UPTC for the financial support under the project SGI-2369.

\section{References}

[1] A. Maniatakou and et al., "Synthesis, structural and DFT studies of a peroxo-niobate complex of the biological ligand 2-quinaldic acid," Polyhedron, vol. 27, no. 16, pp. 3398-3408, Nov. 2008.

[2] C. R. Waidmann, A. G. DiPasquale, and J. M. Mayer, "Synthesis and reactivity of oxo-peroxo-vanadium(v) bipyridine compounds," Inorg. Chem., vol. 49, no. 5, pp. 2383-2391, Jan. 2010.

[3] L. C. Passoni, M. R. H. Siddiqui, A. Steiner, and I. V. Kozhevnikov, "Niobium peroxo compounds as catalysts for liquid-phase oxidation with hydrogen peroxide," J. Mol. Cat. A: Chem., vol. 153, no. 1-2, pp. 103-108, Mar. 2000.

[4] L. C. A. Oliveira and et al., "Pure niobia as catalyst for the oxidation of organic contaminants: Mechanism study via ESI-MS and theoretical calculations," Chem. Phys. Lett., vol. 446, no. 1-3, pp. 133-137, Sep. 2007.

[5] L. J. Burcham, J. Datka, and I. E. Wachs, "In situ vibrational spectroscopy studies of supported niobium oxide catalysts," J. Phys. Chem., vol. 103, no. 29, pp. 6015-6024, Jun. 1999.

[6] D. Bayot, B. Tinant, and M. Devillers, "Water-soluble niobium peroxo complexes as precursors for the preparation of $\mathrm{Nb}$-based oxide catalysts," Catal. Today, vol. 78, no. 1-4, pp. 439-447, Feb. 2003.

[7] M. Kantcheva, H. Budunoğlu, and O. Samarskaya, "Characterization of $\mathrm{Zr}_{6} \mathrm{Nb}_{2} \mathrm{O}_{17}$ synthesized by a peroxo route as a novel solid acid," Catal. Commun., vol. 9, no. 5, pp. 874-879, Mar. 2008.

[8] A. Esteves and et al., "New materials based on modified synthetic $\mathrm{Nb}_{2} \mathrm{O}_{5}$ as photocatalyst for oxidation of organic contaminants," Catal. Commun., vol. 10, no. 3, pp. 330-332, Dec. 2008.

[9] K. T. G. Carvalho, A. C. Silva, L. C. A. Oliveira, M. Gonçalves, and Z. M. Magriotis, "Nióbia sintética modificada como catalisador na oxidação de corante orgânico: utilização de $\mathrm{H}_{2} \mathrm{O}_{2}$ e $\mathrm{O}_{2}$ atmosférico como oxidantes," Quím. Nova, vol. 32, no. 6, pp. 1373-1377, 2009.

[10] T. C. Ramalho and et al., "The molecular basis for the behaviour of niobia species in oxidation reaction probed by theoretical calculations and experimental techniques," Mol. Phys., vol. 107, no. 2, pp. 171-179, Oct. 2010.

[11] L. C. A. Oliveira, M. Gonçalves, D. Q. L. Oliveira, A. L. N. Guarieiro, and M. C. Pereira, "Síntese e propriedades catalíticas em reações de oxidação de goethitas contendo niobio," Quím. Nova, vol. 30, no. 4, pp. 925-929, Aug. 2007.

[12] M. Ziolek and et al., "Catalytic performance of niobium species in crystalline and amorphous solids-gas and liquid phase oxidation," Appl. Catal A: Gen., vol. 391, no. 1-2, pp. 194-204, Jan. 2011.

[13] N. Marin and et al., "Control of the chemoselectivity in the oxidation of geraniol over lanthanum, titanium and niobium catalysts supported on mesoporous silica MCM-41," Top. Catal., vol. 55, no. 7-10, pp. 620-624, Jul. 2012.

[14] N. T. Prado and et al., "Modified niobia as a new catalyst for selective production of dimethoxymethane from methanol," Energy \& Fuels, vol. 24, no. 9, pp. 4793-4796, Aug. 2010.

[15] N. Marin and et al., " $\mathrm{Nb}_{2} \mathrm{O}_{5}$ as heterogeneous catalysts for the selective oxidation of geraniol," Curr. Org. Chem., vol. 16, no. 23, pp. 2797-2801, 2012.

[16] X. Secordel and et al., " $\mathrm{TiO}_{2}$-supported rhenium oxide catalysts for methanol oxidation: Effect of support texture on the structure and reactivity evidenced by an operando raman study," Catal. Today., vol. 155, no. 3-4, pp. 177-183, Oct. 2010.

[17] C. M. de Souza, S. C. de Souza, E. Roditi, and G. Gelbard, “Oxidations of benzyl alcohol by hydrogen peroxide in the presence of complexed peroxoniobium (V) species," J. Chem. Res, (S)., no. 3, pp. 92-93, 1997.

[18] G. Haxhillazi, "Preparation, structure and vibrational spectroscopy 
of tetraperoxo complexes of $\mathrm{Cr}^{\mathrm{V}_{+}}, \mathrm{V}^{\mathrm{V}_{+}}, \mathrm{Nb}^{\mathrm{V}_{+}}$and $\mathrm{Ta}^{\mathrm{V}_{+}, "}$ Ph.D. dissertation, Siegen Univ., Siegen, Germany, 2003.

[19] L. Dragone, P. Moggi, G. Predieri, and R. Zanoni, "Niobia and silica-niobia catalysts from sol-gel synthesis: an $\mathrm{X}$-ray photoelectron spectroscopic characterization," Appl. Surf. Sci., vol. 187, no. 1-2, pp. 82-88, Feb. 2002.

[20] T. C. Ramalho and et al., "The molecular basis for the behaviour of niobia species in oxidation reaction probed by theoretical calculations and experimental techniques," Mol. Phys., vol. 107, no. 2, pp. 171-179, 2009.

[21] F. J. Wong, N. Hong, and S. Ramanathan, “Orbital splitting and optical conductivity of the insulating state of $\mathrm{NbO}_{2}$," Phys. Rev. $B$, vol. 90, no. 11, pp. $115135-1-115135-8$, Sep. 2014.

[22] A. Darlinski and J. Halbritter, "On angle resolved xロray photoelectron spectroscopy of oxides, serrations, and protusions at interfaces," Vac. Sci. \& Technol. A., vol. 5, no. 4, pp. 1235-1240, 1987.

[23] A. B. Posadas, A. O'Hara, S. Rangan, R. A. Bartynski, and A. A. Demkov, "Band gap of epitaxial in-plane-dimerized single-phase Nb02 films," Appl. Phys. Lett., vol. 104, pp. 0929011-09290112, 2014.

[24] Y. Gao, Y. Liang, and S. A. Chambers, "Synthesis and characterization of $\mathrm{Nb}$-doped $\mathrm{TiO}^{2}(110)$ surfaces by molecular beam epitaxy," Surf. Sci., vol. 348, no. 1-2, pp. 17-27, Mar. 1996.

[25] V. V. Atuchin, I. E. Kalabin, V. G. Kesler, and N. V. Pervukhina, "Nb $3 \mathrm{~d}$ and $\mathrm{O} 1 \mathrm{~s}$ core levels and chemical bonding in niobates," J. Elect. Spect. Rel. Phenom., vol. 142, no. 2, pp. 129-134, Feb. 2005.

[26] P. Chagas and et al., "A novel hydrofobic niobium oxyhydroxide as catalyst: Selective cyclohexene oxidation to epoxide," Appl. Catal A
Gen., vol. 454, pp. 88-92, Mar. 2013

[27] B. X. Huang, K. Wang, J. S. Church, and Y. S. Li, "Characterization of oxides on niobium by raman and infrared spectroscopy," Electr. Acta., vol. 44, no. 15, pp. 2571-2577, 1999.

[28] A. A. McConnell, J. S. Aderson, and C. N. R. Rao, "Raman spectra of niobium oxides," Spect. Acta Part A: Mol. Spect., vol. 32, no. 5, pp. 1067-1076, 1976.

[29] F. Somma, A. Puppinato, and G. Strukul, "Niobia-silica aerogel mixed oxide catalysts: Effects of the niobium content, the calcination temperature and the surface hydrophilicity on the epoxidation of olefins with hydrogen peroxide," Appl. Catal A: Gen., vol. 309, no. 1, pp. 115-121, Jul. 2006.

[30] J. M. de S. e Silva, F. S. Vinhado, D. Mandelli, U. Schuchardt, and R. Rinaldi, "The chemical reactivity of some terpenes investigated by alumina catalyzed epoxidation with hydrogen peroxide and by DFT calculations," J. Mol. Cat. A: Chem., vol. 252, no. 1-2, pp. 186-193, Jun. 2006.

[31] A. Feliczak, A. Wawrzyńczak, and I. Nowak, “Selective catalytic oxidations of cyclohexene, thioether and geraniol with hydrogen peroxide. sensitivity to the structure of mesoporous niobosilicates," Micropor. Mesopor. Mater., vol. 202, pp. 80-89, Jan. 2015.

[32] M. P. Chaudhari and S. B. Sawant, "Kinetics of heterogeneous oxidation of benzyl alcohol with hydrogen peroxide," Chem. Eng. J., vol. 106, no. 2, pp. 111-118, Feb. 2005.

[33] A. M. Al-Ajlouni, O. Saglam, T. Diafla, and F. E. Kuhn, "Kinetic studies on phenylphosphopolyperoxotungstates catalyzed epoxidation of olefins with hydrogen peroxide," J. Mol. Cat. A: Chem., vol. 287, no. 1-2, pp. 159-164, May 2008. 